\title{
Assessment of Phytoplankton Diversity in Al-Diwaniya River, Iraq
}

\author{
Khitam Abbas Merhoon $^{1^{*}}$, Foad Manher Alkam² and Muhanned Remzi Nashaat ${ }^{3}$ \\ ${ }^{1}$ Collage of Science, University of AL-Qadisiyah, Iraq. \\ ${ }^{2}$ Collage of Education, University of AL-Qadisiyah, Iraq. \\ ${ }^{3}$ Animal and Fish Resources Center, Agricultural and Biological Research Directorate, \\ Ministry of Science and Technology, P.O.Box 765, Baghdad, Iraq.
}

\section{Authors' contributions}

This work was carried out in collaboration between all authors. Author KAM performed the statistical analysis and wrote the first draft of the manuscript. Author FMA designed the study and wrote the protocol. Authors FMA and MRN managed the analyses of the study. Author MRN managed the literature searches. All authors read and approved the final manuscript.

Article Information

DOI: $10.9734 / A R R B / 2017 / 33228$ Editor(s):

(1) Iskra Ventseslavova Sainova, Institute of Experimental Morphology, Pathology and Anthropology with Museum to Bulgarian Academy of Sciences (IEMPAM - BAS) in Sofia, Bulgaria. (2) George Perry, Dean and Professor of Biology, University of Texas at San Antonio, USA. Reviewers:

(1) I. M. Magami, Usmanu Danfodiyo University, Nigeria. (2) Sophia Barinova, University of Haifa, Israel. (3) Carlos Eduardo de Mattos Bicudo, Institute of Botany, Brasil. Complete Peer review History: http://www.sciencedomain.org/review-history/19887

Original Research Article

Received $5^{\text {th }}$ April 2017

Accepted $16^{\text {th }}$ June 2017

Published 6 ${ }^{\text {th }}$ July 2017

\section{ABSTRACT}

Background and Aim: The present study was conducted to determine the biodiversity of the phytoplankton community in Al-Diwaniya River.

Place and Duration of Study: Al-Diwaniya River in Al-Qadisiyah Province at three stations (station 1 is located to the north of the city, station 2 is located in the city center and station 3 is located south of the city) during four season of 2015.

Methodology: The evaluation included biological aspects using qualitative and quantitative studies of phytoplankton, Species Richness index D, Shannon - Weiner index H, Species uniformity index E.

Statistical Analysis: A comparison of phytoplankton community in two level $30 \mathrm{~cm}$ and $60 \mathrm{~cm}$ from the three stations was investigated.

Results: Current study recorded total number of phytoplankton in depth $30 \mathrm{~cm}$ and $60 \mathrm{~cm}$ ranged 
from 2244.5 to 15104.7 cell $\times 10^{3} \mathrm{~L}^{-1}$ and 965.7 to 5610.4 cell $\times 10^{3} \mathrm{~L}^{-1}$ respectively. Also, two peaks of bloom, the first in spring and the other in autumn, it was founded that the total density in depth $30 \mathrm{~cm}$ was higher than its in $60 \mathrm{~cm}$. Species Richness index values ranged from 6.22 $16.61 ; 5.81-10.64$, More than the values of Shannon Weiner index ranged from 1.51-3.75; 2.35 3.39 bit Ind. $^{-1}$, while Evenness index mean values were $0.47-0.95 ; 0.7-0.96$ for phytoplankton communities in depth $30 \mathrm{~cm}$ and $60 \mathrm{~cm}$ respectively.

Conclusion: Biodiversity indicator showed moderate pollution and good diversity of Al-Diwaniya River at the station 2, while a poor diversity and contaminated at the station 3 due to expose to environmental stresses from of industrial, residential waste and wastewater effect.

Keywords: Phytoplankton; biodiversity; Al-Diwaniya River; Shannon Weiner index.

\section{INTRODUCTION}

The primary productivity is proceeded of photosynthesis and production of life, which has the primary role in the function of the ecosystem and the source for the manufacture of chemical energy and organic materials for various aquatic ecological communities by converting solar energy into chemical energy that benefits for all organisms [1,2].

Phytoplankton represents the basic level of a food chain in the aquatic environment, it represents a primary food source in these ecosystems, due to it turned solar energy in the presence of water and carbon dioxide into organic compounds by the photosynthesis [3]. The advantage of phytoplankton being highly sensitive to changes in environmental conditions, as some of the biological factors affect on the presence and abundance of phytoplankton, which (temperature, $\mathrm{pH}$, turbidity, and electrical conductivity and salinity, sodium, potassium, calcium, nitrate, and phosphate) The fact that phytoplankton are very sensitive to change the properties of water and nutrients in particular as well as the possibility of some of them used as indicators on water quality [4]. It can also be used to assess the biodiversity in water bodies.

The biodiversity represents the variation in all forms of life, starting from the species through the geneses to the ecosystems where there are organisms, since all ecosystems depended on a balanced and accurate diversity system complements one another, else is losing species or group of species in this ecosystem signal to a defect in the function of the system [5]. The biodiversity measuring guide for assessing water quality through the use of bio-monitoring in the aquatic environment, which includes the study of the quantity and quality to understand the complex relationships between organisms and their response and how Its resistance to environmental influences [6]. So by using a set of biodiversity evidenced to describe the components and study of a community of organisms that live in the aquatic environment and characterized by undemanding and free of complexity and reveal environmental factors, biotic and a biotic factors that affecting on them [7].

Numerous studies on the diversity of phytoplankton were conducted and abundant in different regions of the world, as it was noted that some types of phytoplankton density and abundance, diversity and distribution, installation and appearance and disappearance is directly dependent on the living and non-living aquatic environment factors $[8,9,10,11,12,13]$.

\section{MATERIALS AND METHODS}

Al-Diwaniya River, 123 km-long, about 20-25 m wide and a depth ranging from 2-4 $\mathrm{m}$. Three stations were selected in Al-Diwaniyah River for the purpose of the study. The station 1 is located to the north of the city center, the river at this station is surrounded by some agricultural land and is characterized by being a breeding area for the buffalo, and this plant is free of aquatic plants on both sides of the river. Station 2 is located in the city center; It is characterized by the presence of many pollutants that are received directly in the water of the river and contains many aquatic plants on both sides of the river. Station 3 is located south of the city, characterized by a lack of aquatic plants on both sides of the river, as well as being exposed to pollution residues and laboratory textile rubber plant and sewage treatment (Fig. 1). Phytoplankton samples were collected from the middle of the river for the entire year by water sampler (2.5 liter), the sample was preserved with Lugol solution and use method of deposition 

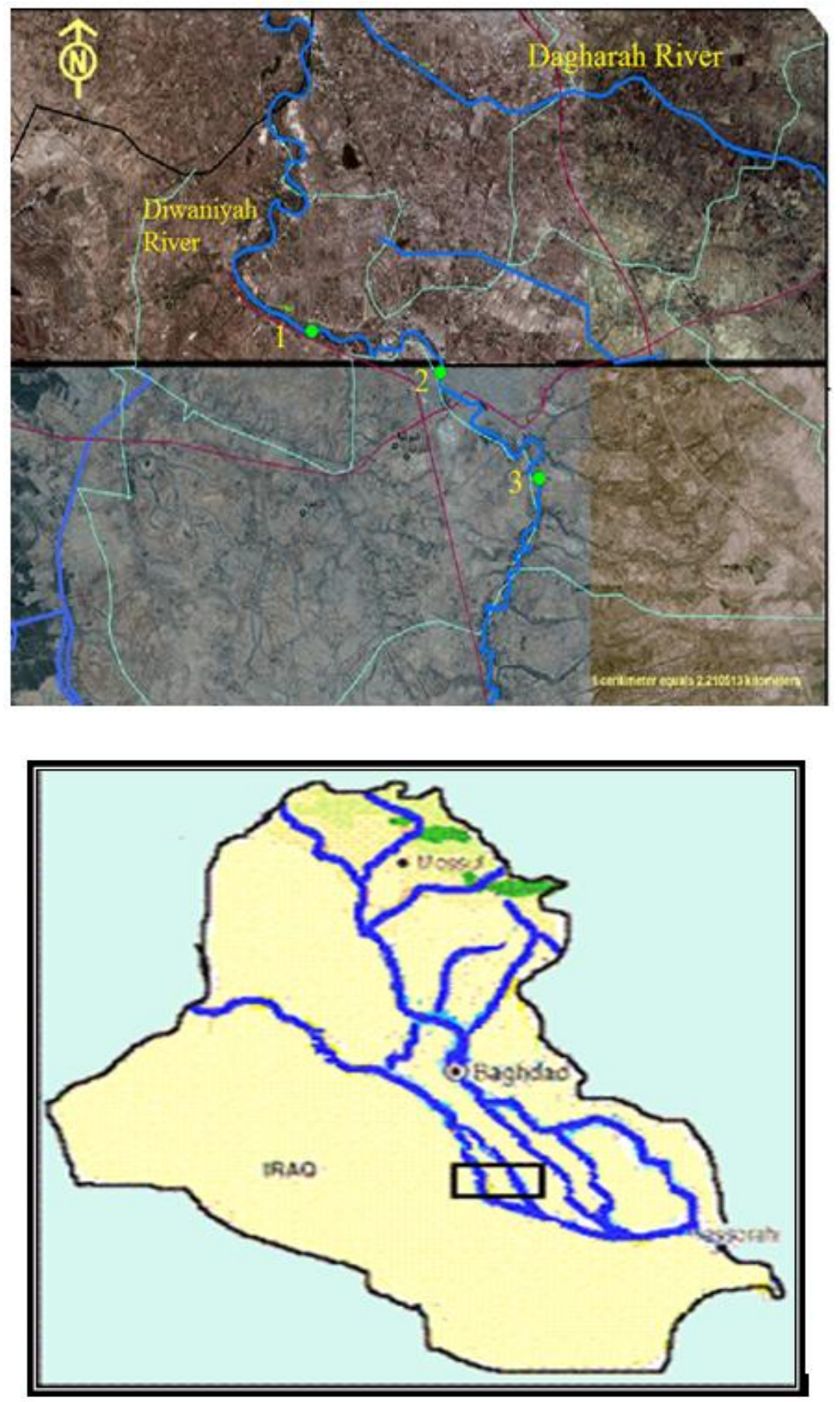

Fig. 1. A map of the Al-Diwaniya River explaining the study stations

and concentration to $10 \mathrm{ml}$ for the purpose of calculating the numbers of phytoplankton by following the method described by [14].

The diversity of the phytoplankton was evaluated by adopting the indices below.
1. Species Richness Index [15] according to the following formula:

$\mathrm{D}=(\mathrm{S}-1) /(\log N)$

$S=$ the number of species.

$\mathrm{N}=$ total number of individuals. 
2. Shanon-Weiner Diversity Index [16] and according to the following formula:

$$
\begin{aligned}
\mathrm{H}= & -\sum \frac{\mathrm{ni}}{\mathrm{N}} * \operatorname{Ln} \frac{\mathrm{ni}}{\mathrm{N}} \\
\mathrm{ni}= & \text { number of individuals of each type. } \\
\mathrm{N}= & \text { total number of individuals. And } \\
& \begin{array}{l}
\text { expressed of the results the unity bit } \\
\text { Ind. }
\end{array}
\end{aligned}
$$

3. Species Uniformity Index (Evenness Index) [17], according to the following formula: -

$$
\begin{aligned}
& \mathrm{E}=\frac{\mathrm{H}}{\mathrm{LnS}} \\
& \text { LnS = greater theoretical value of diversity } \text {. } \\
& \mathrm{H}=\text { the value of the standard Shannon } \\
& \text { Weiner. } \\
& S=\text { the number of species at the station. }
\end{aligned}
$$

\section{RESULTS AND DISCUSSION}

\subsection{Total Density of Phytoplankton}

Total density refers to the total number of organisms in a specific area or a certain size [18]. It was observed from the study period, in which two peaks were assessed - one in the spring and the other in autumn. Also, it was noted that phytoplankton appeared with the highest density at the surface when compares its presence in the depths specially when reached to the peak density, furthermore, it was recorded a value of the total density of phytoplankton in the depth of $30 \mathrm{~cm}$ ranged from 15104.7 2244.5 cell $\times 10^{3} \mathrm{~L}^{-1}$ during the spring and winter at stations 2 and 3 respectively, while the total density of phytoplankton in the depth $60 \mathrm{~cm}$ has ranged from $5610.4-963.7$ cell $\times 10^{3} \mathrm{~L}^{-1}$ during the spring and winter, at the stations 2 and 3 respectively (Table 1 , Fig. 2 ).

The lowest values of the seasonal variation of the total phytoplankton density values were recorded during in winter followed by summer and this decline in density values may be attributable to the low temperatures in the winter and higher in the summer, which caused a slow growth rate of algae $[19,20]$. On the other hand the reason for the rise in total numbers of phytoplankton in the spring and autumn may be due to the availability of suitable environmental conditions for the growth, reproduction of the mild temperatures, the availability of dissolved oxygen, nutrients and suitable light intensity for growth [19,21].

As for the location changes, station 2 recorded highest recorded values of the total density of phytoplankton, and this is due to the large number of aquatic plants at this station, which provides a favorable environment for the growth of phytoplankton, as well as the shallowness of the water, increasing transparency and access sunlight into different depths of water [22]. While the decline in their numbers at the station 3 as a result of the large number of pollutants that pose in the river from industrial and residential waste, which can be toxic for the phytoplankton, causing a lack of preparation [23,24].

Concerning on a vertical distribution of phytoplankton, it can be noted that the total numbers which observed at a depth of $30 \mathrm{~cm}$ higher than at the depth of $60 \mathrm{~cm}$ which may be related to provide optimal light intensity in the river surface compared to $60 \mathrm{~cm}$ depth. In addition to that the decreased number of phytoplankton may be due to increase turbidity in surface, presence of solid particulate matter, with developed by a large number of microorganisms and the presence of some floating plants which are decreasing part of the light to reach to the depths and thus lack phytoplankton get sufficient light quantity to do the photosynthesis process, which associated with reduces the total amount of phytoplankton $[25,26]$. Perhaps attributed the low total numbers of phytoplankton at depths to expose by zooplankton predation, which increases their density in the depths during the day [27].

\subsection{Biodiversity Indexes}

\subsubsection{Species richness index (D)}

The value of the species richness index at a depth of $30 \mathrm{~cm}$ were varied from 16.62 at station 2 during the spring of 6.23 were observed at station 3 during the summer, whereas at the depth of $60 \mathrm{~cm}$ was ranged from 5.81-10.65 during the summer and autumn at station 2 and 3 respectively (Table 1, Fig. 3 ). It was observed from the results there is a difference in the value of the index between stations and seasons and depths, but it was mostly just in the station 2 and the first during the spring, then autumn and summer and was at the surface higher than at depths, this is a result from the light effect [28]. 
Merhoon et al.; ARRB, 14(2): 1-9, 2017; Article no.ARRB. 33228

Table 1. Ranges of total number of phytoplankton and biodiversity index at Al-Diwaniya River in depth $30 \mathrm{~cm}$ and $60 \mathrm{~cm}$ during study period

\begin{tabular}{|c|c|c|c|c|c|c|c|}
\hline \multirow[t]{2}{*}{ Parameter } & \multirow{2}{*}{$\begin{array}{l}\text { Stations } \\
\text { Depth }\end{array}$} & \multicolumn{2}{|l|}{1} & \multicolumn{2}{|l|}{2} & \multicolumn{2}{|l|}{3} \\
\hline & & $30 \mathrm{~cm}$ & $60 \mathrm{~cm}$ & $30 \mathrm{~cm}$ & $60 \mathrm{~cm}$ & $30 \mathrm{~cm}$ & $60 \mathrm{~cm}$ \\
\hline Total numb & kton $\left(\right.$ cell $\left.\times 10^{3} \mathrm{~L}^{-1}\right)$ & $13569.5-2707.9$ & $965.7-3669$ & $3094.7-15104.7$ & $1112.9-5610.4$ & $2244.5-9419.9$ & $1035.1-3507.1$ \\
\hline Species Ric & ) of phytoplankton & $11.36-15.22$ & $6.27-9.53$ & $6.22-16.61$ & $5.81-8.53$ & $10.23-12.23$ & $8.37-10.64$ \\
\hline Shannon an & $(\mathrm{H})$ of phytoplankton(bit Ind. ${ }^{-1}$ ) & $2.95-3.75$ & $2.49-2.75$ & $1.51-3.40$ & $2.35-2.78$ & $2.37-3.38$ & $2.69-3.39$ \\
\hline Evenness Ir & toplankton & $0.71-0.95$ & $0.7-0.89$ & $0.47-0.83$ & $0.71-0.81$ & $0.66-0.90$ & $0.79-0.96$ \\
\hline
\end{tabular}

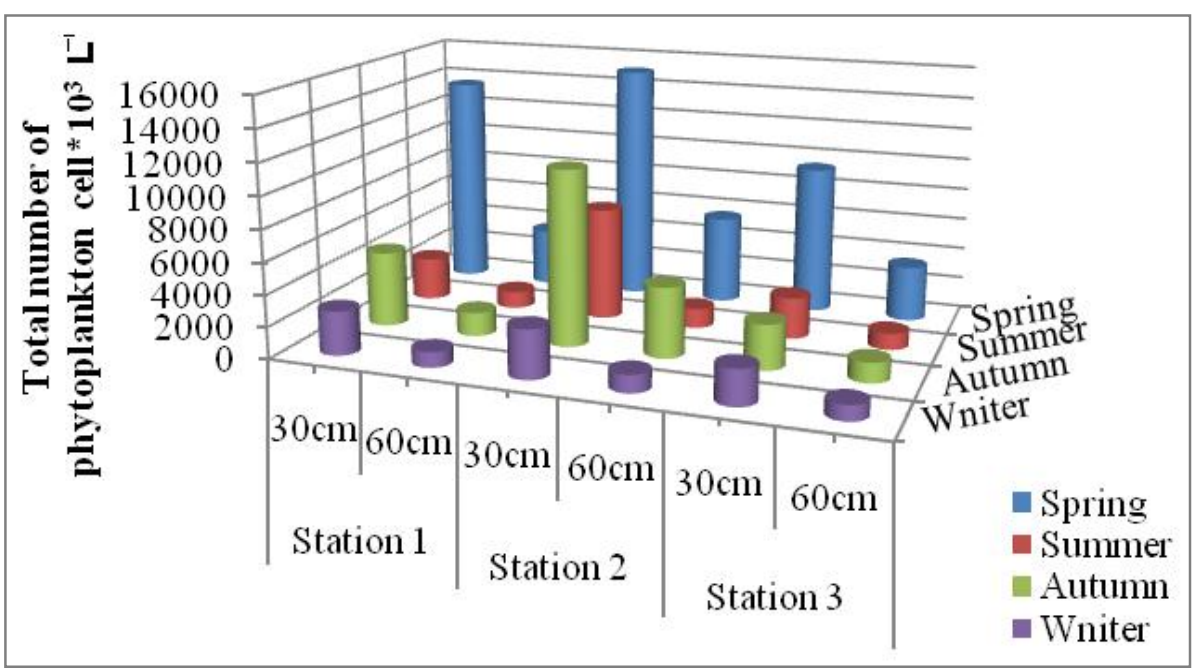

Fig. 2. Number of phytoplankton cell according to season 


\subsubsection{Shannon-Weiner index $(\mathrm{H})$}

The Shannon - Weiner Index is considered one of the environmental indicators that referred to the number of species in the sample and the distribution of individuals between these species, though the change in the values of this index expresses and the change in the characteristics of the water [29].

Table 1 and Fig. 4 shows Shannon - Weiner diversity value of study station, the highest value of diversity recorded at station 1 at a depth of 30 $\mathrm{cm}$ was 3.75 bit Ind. $^{-1}$ during spring, while the lowest value were 1.52 bit Ind..$^{-1}$ at station 2 during summer. Whereas in the depth of $60 \mathrm{~cm}$ ranged from 2.49-3.39 bit Ind. $^{-1}$ during spring and autumn at station 1 and 3 , respectively.

The registration high values of biodiversity in the spring season was associated with increased primary productivity in this seasons from phytoplankton bloom [30], As well as the variation of this index according to the changes of depth were recorded higher values at station 2 due to the presence of aquatic plants and a lack of flow velocity, while the lowest values were at station 3 which may be related with the seasonal variation of salinity, increased flow velocity, very low values of dissolved oxygen and increased organic pollution that resulting from the discharge of sewage [31]. It was found from the current study the values of Shannon-Weiner were ranging from 1-3 bit Ind. ${ }^{-1}$. Neves et al. [16] noted that the biodiversity values ranging from 0 5 , and the values that most of the 3 bit Ind. ${ }^{-1}$ referred to a high diversity, while indicating at least 1 bit Ind. $^{-1}$ to the presence of environmental pressures. Also, this index is a measure of the quality of water and the extent of contamination [32]. So, it can be noted that the water of the AlDiwaniyah River was considered poor water to a moderate diversity, can also be regarded as a moderate pollution.

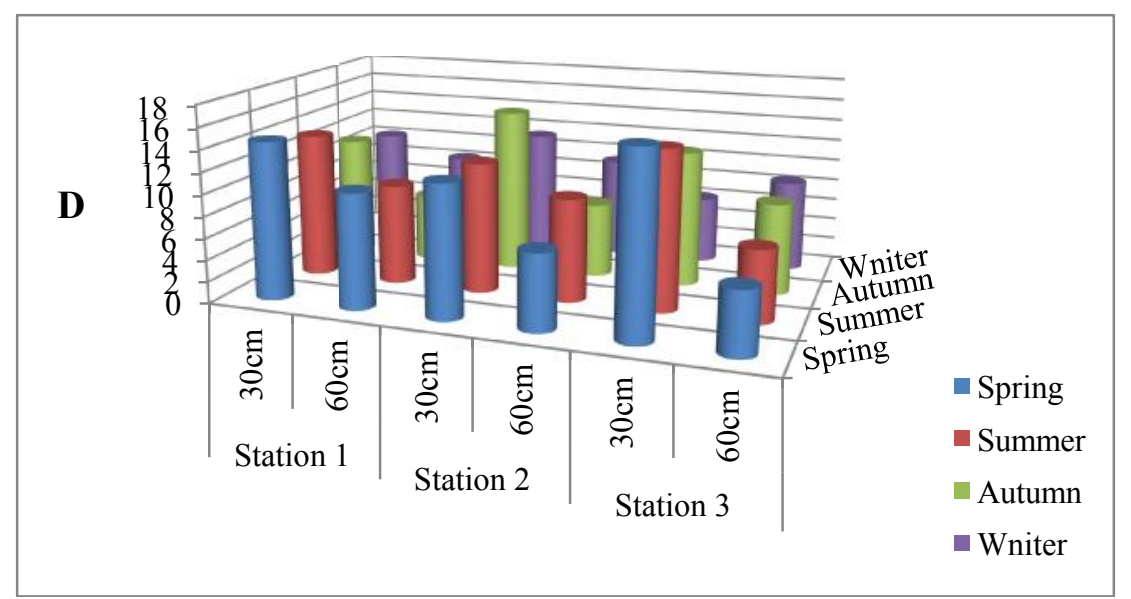

Fig. 3. Seasonal changes of species richness index of phytoplankton according to season

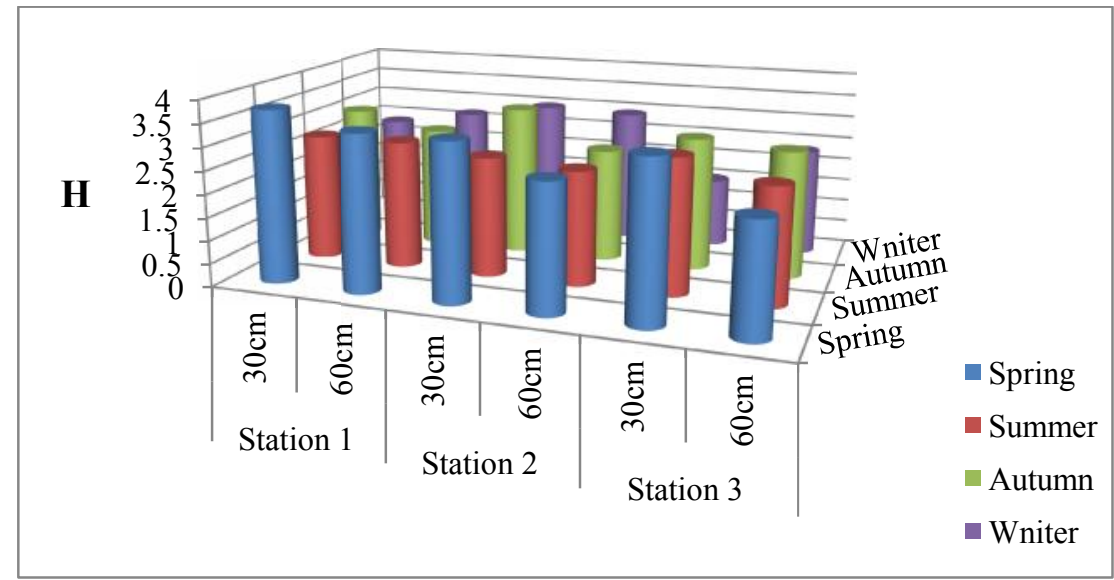

Fig. 4. Seasonal changes of Shannon-Weiner index of phytoplankton according to season 


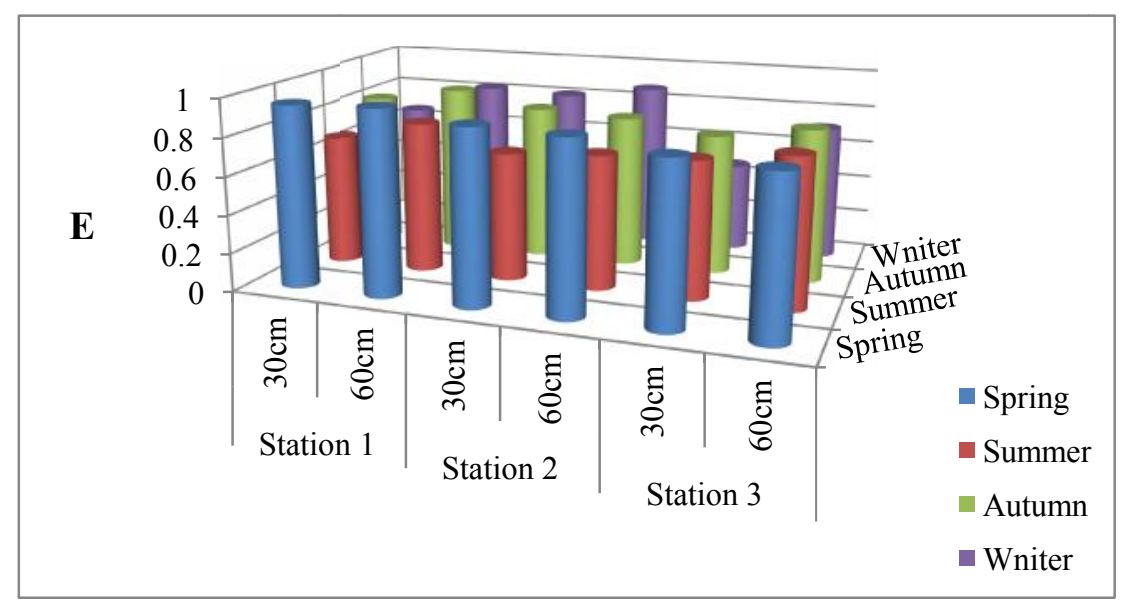

Fig. 5. Seasonally changes of evenness indices of phytoplankton according to season

\subsubsection{Species evenness index $(E)$}

It represents homogeneity evidence for the emergence of the species distribution pattern of individuals between the sample types, since the density of individuals approaching each other to make some of the guide values closer to 1 [33].

The present study recorded the highest value of species evenness index for a depth of $30 \mathrm{~cm}$ was 0.95 during the winter at the station 1 whereas the lowest value was 0.47 during the summer at station 2. On the other hand on the depth of 60 $\mathrm{cm}$ the highest value was 0.96 recorded in the autumn at station 3 while the least during the spring at station 1, was 0.7 (Table 1, Fig. 5).

According to the results obtained, the recorded differences between stations, seasons and depths due to the variation in the nature of the environmental conditions may be suitable or unsuitable for the growth and the presence of phytoplankton [34]. As higher values recorded in the presented study indicate the availability of suitable environmental conditions for the stability of species, it has mostly exceeded 0.5 , indicating that the species homogeneous to appear within a single sample. Low values of the index may be from an ecological pressure.

\section{CONCLUSION}

Biodiversity indicator showed that Al-Diwaniya River has moderate pollution and good diversity at the station 2, but also a poor diversity and contaminated at station 3 due to expose to environmental stresses from industrial, residential waste and wastewater effect.

\section{COMPETING INTERESTS}

Authors have declared that no competing interests exist.

\section{REFERENCES}

1. Mishra SR, Saksena DN. The primary productivity of phytoplankton in a sewage collecting Morar (Kalpi) river at Jaderrua Bundha, Gwalior, Madhya Pradesh. Journal of Inland Fisheries Society India. 1992;24(1):61-68.

2. Lee $S$, Joo $H$, Liu $Z$, Chen J, He J. Phytoplankton Productivity in newly opened waters of the western Arctic Ocean. Deep-Sea. Res. Part II: Tropical Studies in Oceanography. 2012;81-84:1827.

3. Maar M. Distributions of zooplankton in relation to biological- physical factors. Ph.D. Thesis, National Environmental research Institute. Department of Marine Ecology, University of Aarhus, Denmark; 2003.

4. Fonge B, Tening A, Egbe E, Yinda G, Fongod A, Achu R. Phytoplankton diversity and abundance in Ndop Wetland Plain, Cameroon. Afr. J. Environ. Sci. Tech. 2010;6(6):248-257.

5. Fausch KD, Lyons J, Karr JR, Angermeier $\mathrm{PL}$. Fish communities as indicators of environmental degradation. In: Biological indicators of stress in fish. S.M. Admes (Eds.). American; 1990.

6. Sharma MS, Sharma V, Malara $H$. Biodiversity of zooplankton in relation to different types of aquatic pollution. C.P. 46. NSL 2007. 2007;300-302. 
7. Werner I, Clark S, Hinton DE. Biomarkers aid understanding of aquatic organism responses to environmental stresses. California Agriculture. 2003;57(4):110-115.

8. Escaravage V, Prins $T$. Silicte availability vertical mixing and grazing control of Phytoplankton blooms in meso coms Hydrobiologia. 2002;484:33-48.

9. Kauppila P, Pitkänen $H$, Räike A, Kiirikki $M$, Bäck S, Kangas P. The Baltic waters around Finland: Eutrophication continues despite decreased nutrient loading. In: Eloranta, P. (ed.) Inland and coastal waters of Finland. SIL XXIX Congress, Lahti, Finland, 8-14 August 2004. University of Helsinki. 2004;41-62.

10. Komala H, Nanjundaswamy L, Prasad G. An assessment of plankton diversity and abundance of Arkavathi River with reference to pollution. Adv. Appl. Sci. Res. 2013;4(3):320-324.

11. Gupta S, Dixit S, Tiwari S. An assessment of Heavy metals in surface water of lower lake, Bhopal, India, Poll. Res. 2005;24(4): 805-808.

12. Lequere C, Harrison S, Prentice I, Buitenhuis E, Aumont O, Bopp L, Clauster $H$. Ecosystem dynamic based on plankton functional type for Global ocean biogeochemistry models. Global. Change Biol. 2005;11:2016-2040.

13. Cermeno $P$, Ramos $T$, Dorneles $M$, Figueras F, Maranon E, Teixeira I, Vallina S. Species richness in marine Phytoplankton communities is not correlated to ecosystem productivity. Mar. Ecol. Prog. Ser. 2013;488:1-9.

14. Hadi RAM. Algal studies on the river usk. Ph.D. Thesis, Univ. College Cardiff U.K; 1981.

15. Sklar FH. Seasonality and community structure of the Backswamp invertebrates in Louisiana cypress-tupelo wetlands. Wetlands J. 1985;5:69-86.

16. Neves IF, Rocha O, Roche KF, Pinto AA. Zooplankton community structure of two marginal lakes of the river Cuibá (Mato Grosso, Brazil) with analysis of Rotifera and Cladocera diversity. Braz. J. Biol. 2003;63:329-343.

17. Floder S, Sommer $U$. Diversity in planktonic communities: An experimental test pf the intermediate disturbance hypothesis. Limno. Oceanogr. 1999;44(4): 1114-1119.

18. Porto-Neto VF. Zooplankton as bioindicator of environmental quality in the
Tamandane Reff System (PernambncoBrazil): Anthropogenic influences and interaction with mangroves. Ph.D. Thesis, Univ. Bremenm Brazil; 2003.

19. Elliott JA, Jones ID, Thackeray SJ. testing the sensitivity of phytoplankton communities to changes in water temperature and nutrient load, in a temperate lake. Hydrobiologia. 2006;559: 401-411.

20. Sin $Y$, Wetzel RL, Lee BG, Kang $\mathrm{YH}$. Integrative ecosystem analysis of phytoplankton dynamics in the York River estuary (U.S.A). Hydrobiologia. 2006;571: 93-108.

21. Shah MR, Hossain $Y$, Begum M, Ahmed Z, Ohtomi J, Rahman M, Alam J, Islam A, Fulanda B. Seasonal variations of phytoplankton community factors of the south west coastal water of Bangladesh. J. Fish. Aqut. Sci. 2008;3(2):102-113.

22. Dimowo BO. The phytoplankton species Composition and Abundance of Ogun River, Abeokuat South western Nigeria. Intern. J. Aquac. 2013;3(2):4-7.

23. Ariyadej $\mathrm{C}$, tansakul $\mathrm{R}$, Tansakul $\mathrm{P}$, Angsupanich S. Phytoplankton diversity and it's relationships to phsico- chemical environment in Ban, lang Reservoir. Yala Provinc. 2004;26(5):595-606.

24. Al-Zubaidi KAM, Alkam FM. The impact of Al- Diwanyia Textile Factory Discharges on Water Quality of Al- Diwanyia River -Iraq. J. of AL-Qadisiyah for Sci. 2012;17(2): 58-69.

25. Ahmed A, Alflasane MA. Ecological studies of the River padma at mawa Ghat, Munshiganj- II. Primary productivity, phytoplankton standing crops and diversity. Pakistan J. of Biolo. Sci. 2004; 7(11):1870-1875.

26. Oliver RL, Ganf GG. Freshwater blooms, In: The Ecology of cyanobacteria. Their Diversity in time and space. Whitton, B. A. and M. Potts (Eds.) Kluwer Academic publishers, Dordrecht. The Netherlands. 2000;669.

27. Siddhartha R, Kumari R, Tanti K, Pandey B. Diel variations of physico-chemical factors and plankon popution in a swamp of Harda, Purnia, Bihar (India). Intern. J. Scien. Resear. Publ. 2012;2(6):1-4.

28. Ghosh S, Barinova S, Keshri JP. Diversity and seasonal variation of phytoplankton community in the Santragachi Lake, West Bengal, India. QScinece Connect. 2012;3: 1-19. 
29. An XP, Du ZH, Zhang JH, Li YP, Qi JW. Structure of the Zooplankton in Hulun Lake, China. Procedia Environmental Sciences. 2012;13:1099-1109.

30. Salman JM, Nassar AJ. The biodiversity of some Gastropods species in Euphrates River in Iraq. The 4Th Environmental Science Conference University of Babylon, 5-6 December, 2012, Iraq.

31. Tumas R. Lithuanian Kart region rivers water ecology, hydrochemical and hydrobiological evaluation. Nordic Hydrol. 2003;35(1):61-72.
32. Goel PK. Water pollution. Causes, effects and control. $2^{\text {nd }} \mathrm{Ed}$, Reprint New Age international (P) Limited, Publishers, New Delhi. 2008;285.

33. Ricotta C, Avena G. On the information theoretical meaing of Hill, sparametric Evennes. Acta Biotheoretica. 2002;30:6371.

34. Kadhim NF. Study of some physical and chemical properties and their effects on Epipelic algae diversity, in $\mathrm{AL}$ Abbasyah/AL-Kufa Distract. Journal of Babylon University. 2014;2(22):701-725.

(c) 2017 Merhoon et al.; This is an Open Access article distributed under the terms of the Creative Commons Attribution License (http://creativecommons.org/licenses/by/4.0), which permits unrestricted use, distribution, and reproduction in any medium, provided the original work is properly cited.

Peer-review history:

The peer review history for this paper can be accessed here: http://sciencedomain.org/review-history/19887 